\title{
Determination of Accident Rates in the City of Barranquilla in Northern Colombia
}

\author{
Fernando Jove Wilches*1, Rodrigo Hernández Avila ${ }^{1}$ and Álvaro Rafael Caballero Guerrero ${ }^{2}$ \\ ${ }^{1}$ Department of Civil Engineering, Universidad de Sucre, Sincelejo, Sucre, Colombia. \\ ${ }^{2}$ Department of Civil and Environmental Engineering, Universidad del Norte, Barranquilla, Colombia.
}

ORCIDs: 0000-0002-2080-4036 (Fernando), 0000-0003-3178-8075 (Rodrigo), 0000-0002-3567-9135 (Álvaro)

\begin{abstract}
Traffic accidents are one of the problems that generate the greatest impact in today's society. In Colombia, traffic accidents claim thousands of lives each year, a large number of injured and huge economic losses due to material damage. To find efficient solutions to mitigate this problem, it is necessary to have information that allows to recognize the characteristics, causes and results of accidents. Accident data provides a vision of the characteristics and conditions of traffic accidents in a city or region and helps to carry out studies and analyzes aimed at diagnosing the possible causes of accidents, in order to create and implement systems and regulations that help to minimize the degree of accidents and increase the degree of safety of a road system. This document is based on information regarding all traffic accidents registered by the authorities in the city of Barranquilla, department of Atlántico, in northern Colombia. The data collected covers a period of 5 consecutive years, beginning in January 2015 and ending in December 2019. The information corresponds to a collection of data from the websites of the Departamento Administrativo Nacional de Estadística (DANE). To obtain the accident statistics, the following variables were taken into consideration: the date of the accidents (hour, day, month and year), the number of injured and killed in accidents, the type of accidents and the severity of the accidents. Additionally, the behavior of four accident rate indicators determined from the information collected and consolidated is shown. According to the results obtained, it could be established that the mortality and fatality rates presented the highest values for the year 2016.
\end{abstract}

Keywords: Road Safety, Traffic Accidents, Urban Roads, Mortality rate, Injury rate, Fatality rate

\section{INTRODUCTION}

A traffic accident is an event in which, within the context of driving a motor vehicle, there is damage, whether material or human, and where the physical integrity of at least one person is put at risk [1]. It can also be described as "a road mishap that occurs suddenly and unexpectedly, which is determined by partially foreseeable irresponsible acts and conditions, attributed to human factors, motor vehicles, weather conditions, signage or state of the road network, which usually cause premature loss of life and/or injured, as well as physical or psychological consequences, material compensations and damages to third parties [2].

Road accidents constitute one of the problems that has the greatest impact on the well-being of today's society, since it generates worldwide a high number of victims, including deaths and injured, as well as large material losses [3], [4]; therefore, it is up to governments to provide timely attention to this problem for humanitarian, public health and economic reasons [5]. For this reason, it is of particular interest for traffic engineering to address the study of road accidents, in such a way that the possible causes are determined, in order to take measures leading to the improvement of road safety conditions, in those aspects that can be improved and that are under the control of the traffic engineer and the authorities, such as the design of road solutions that are compatible with the operating conditions of the vehicles, road safety campaigns, implementation of adequate signage and police surveillance; so that the physical integrity of users can be preserved, also preventing huge economic losses [3], [6].

In order to quantify the degree of impact that in terms of accidents occurs in a given geographical area, a series of indicators have been developed that allow establishing the level of seriousness of the matter, which allow making comparisons in relation to the number of accidents that occurred at the same site for different times or at different sites during the same period of time. For this purpose, there are accident rates based on the number of inhabitants, the number of vehicles and the traffic [4].

The objective of this work was focused on the determination of several representative accident rates of the urban area of the city of Barranquilla, located in the north of Colombia. To achieve this goal, the information corresponding to the accident registry collected by the city's traffic authorities, which occurred within its urban area, during the period between January 2015 and December 2019 was analyzed. By contrasting this information with some variables of interest, Mortality rate, Injury rate, Fatality rate could be determined, which were obtained based on the relationship between two variables, respectively: the number of deaths with the total population, the number of injured with the total population and the number of deaths with the total number of injured in accidents. 
International Journal of Engineering Research and Technology. ISSN 0974-3154, Volume 13, Number 10 (2020), pp. 2864-2869

(C) International Research Publication House. https://dx.doi.org/10.37624/IJERT/13.10.2020.2864-2869

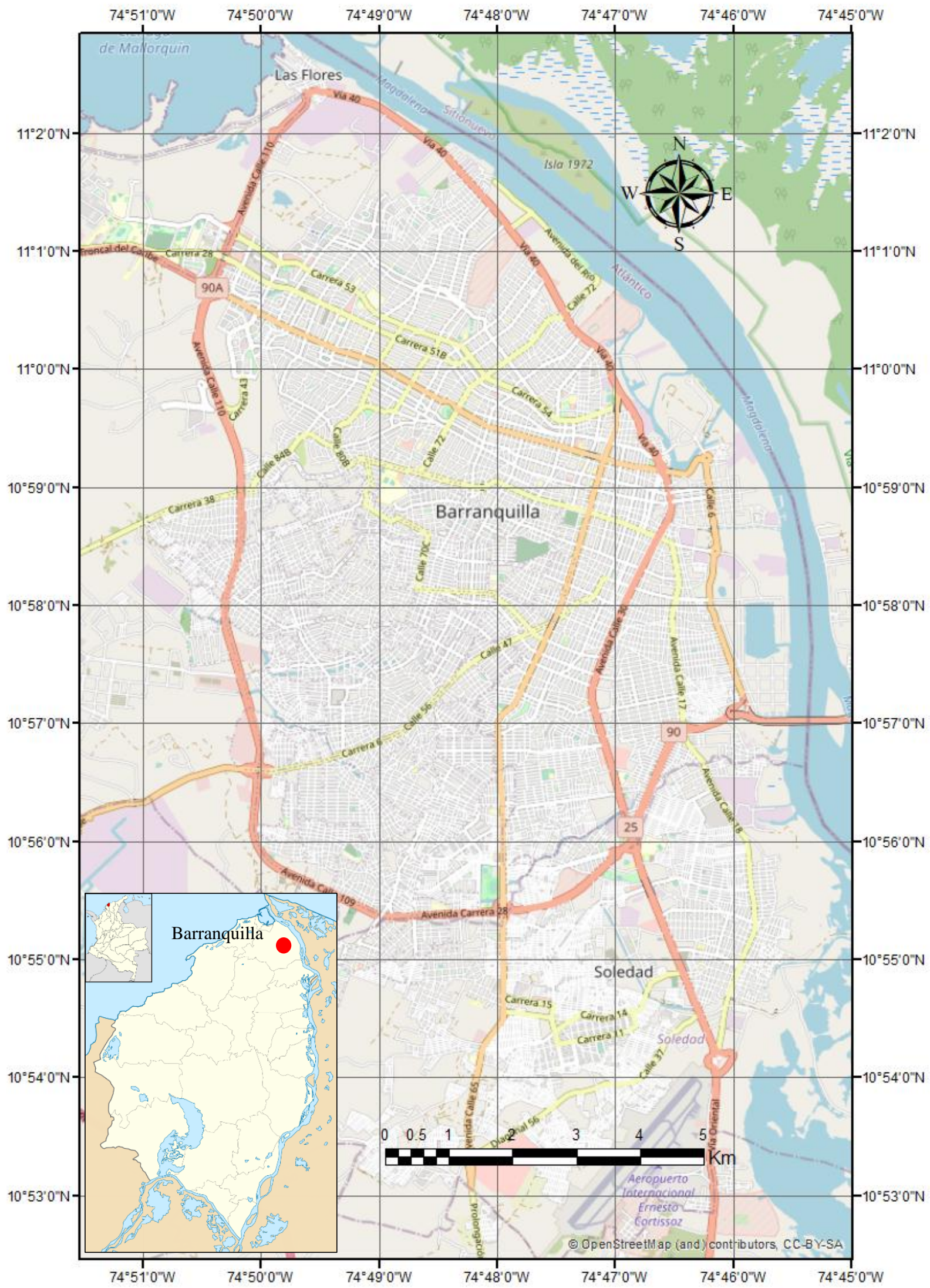

Fig 1. Location of Barranquilla city in the department of Atlántico (Colombia) 


\section{EXPERIMENTAL DESIGN, MATERIALS AND METHODS}

\section{II.I Study area description}

Barranquilla, officially Distrito Especial, Industrial y Portuario de Barranquilla, is the capital of the department of Atlántico. It is located in the north of Colombia, on the western bank of the Magdalena River, $7.5 \mathrm{~km}$ from its mouth in the Caribbean Sea. It is the main economic center of the Caribbean Region of Colombia. Among the economic activities, trade and industry stand out. Barranquilla's population estimated for the year 2020 is approximately 1.2 million inhabitants [7], which makes it the fourth most populous city in the country behind Bogotá, Medellín and Cali. The city is the nucleus of the Metropolitan Area of Barranquilla, which is also constituted by the municipalities of Soledad, Malambo, Galapa and Puerto Colombia. Barranquilla's climate is tropical dry. The average temperature is $27.4^{\circ} \mathrm{C}$ [8].

Fig. 1 shows the urban area of the city of Barranquilla, being able to highlight the road network of the city, in which the information object of this work was collected.

\section{II.II Material and methods}

The data was collected from a period of 5 consecutive years, corresponding to the years 2015, 2016, 2017, 2018 and 2019. To create the database, the most relevant information was filtered and organized, thus creating a comprehensive database.
For this, the columns of the file correspond to all the variables obtained from the main databases or the variables that were derived from them. On the other hand, the rows show the periods discriminating them by accident, that is, each accident is recorded individually, separating them by hour and day. The data representing the dates was sorted in ascending order, beginning in January 2015 and ending in December 2019.

The first six columns were used to show the exact date of the accidents within the period in which the data were collected, having the information broken down by hour, day, month and year. Then the severity of the accident is shown (accident that left only material damage, accidents with only injuries, accidents with only deaths, accidents with deaths and injuries) and the classification of traffic accidents (Crash, Run-over, Rollover, Occupant Fall, Fire or others). After it is presented, the number of injured and the number of fatalities in traffic accidents. To complement the information, the data of the census and estimated Barranquilla population for the years of the study period were added. From the above information, it was possible to determine Mortality rate, Injury rate, Fatality rate and the ratio of deaths by accident, making use of time components [9], the periods in this study are expressed in years for the calculation of said indicators. For the calculation of these indicators, equations 1, 2, 3 and 4 [10] were followed. The information obtained helps to describe the behaviour of the accident rate and the impact it generates, in order to promote policies, strategies or strategic programs that promote road safety in the urban area of the city.

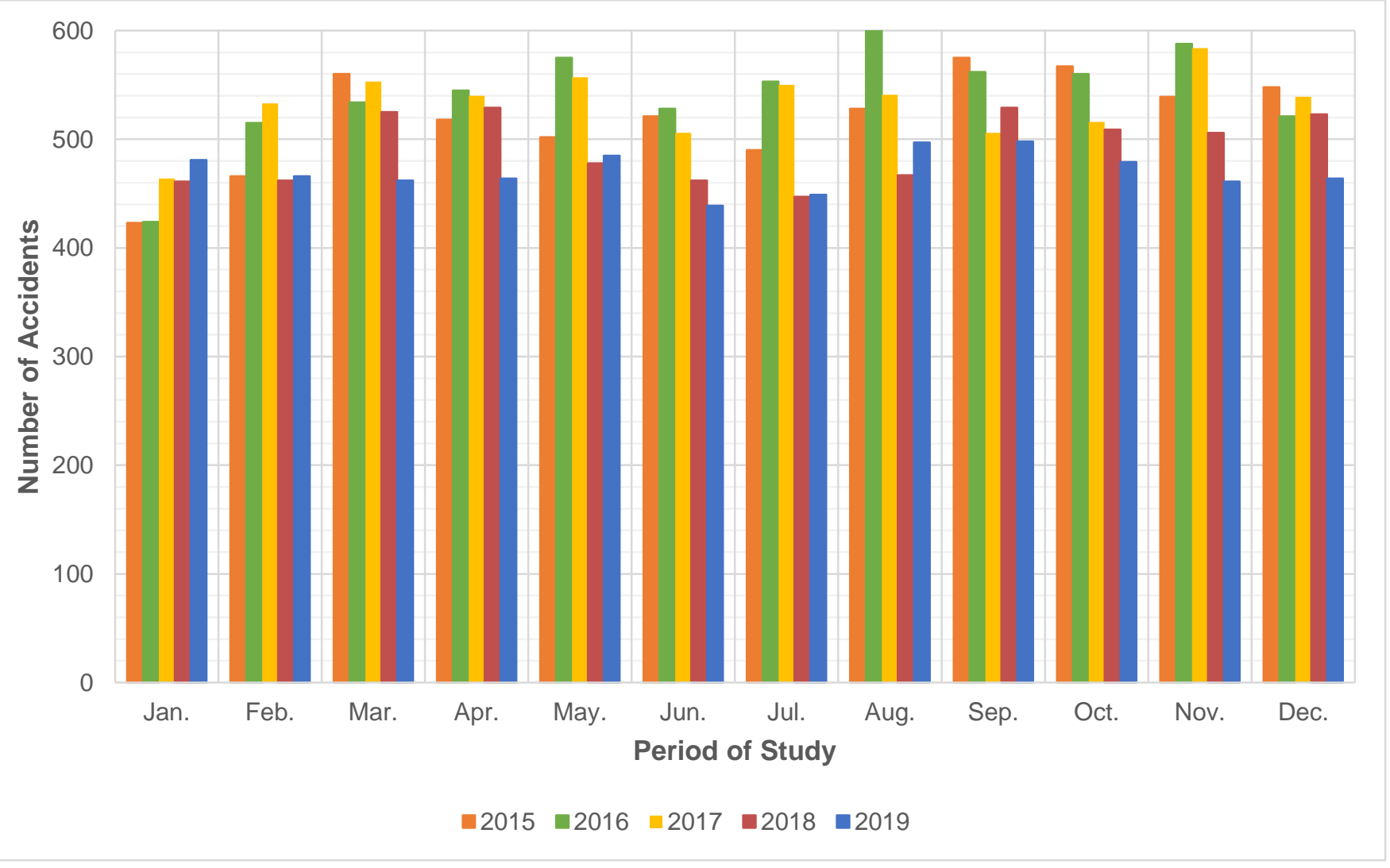

Fig. 2. Road traffic accident in Barranquilla city, 2015 - 2019 
International Journal of Engineering Research and Technology. ISSN 0974-3154, Volume 13, Number 10 (2020), pp. 2864-2869

(C) International Research Publication House. https://dx.doi.org/10.37624/IJERT/13.10.2020.2864-2869

\section{RESULTS}

Accident rates were determined from data obtained from the Colombian Government website, referring to accidents occurring within the urban area of the city of Barranquilla. Additionally, figures and tables were built showing the main data analyzed. The information collected presents the historical records of the accident figures for the last 5 years, between 2015 and 2019.

In Figures 2, 3 and 4, the number of accidents, the number of injuries and the number of deaths are shown for each month and year, respectively. In these Figures it can be seen how the indicators represented vary over time.
In Table 1, a summary of the severity of the accident is presented, categorized into: accidents with only injuries, accidents with only injuries, accidents with only deaths, and accidents with injuries and deaths. Table 2 shows an annual summary of the number of types of accidents, the categories are: Crash, Run over, Rollover, Occupant Fall, Fire and Others.

Fig. 5 represents the number of accidents, deaths and injuries, year by year, during the study period. Finally, Table 3 shows a summary of the characteristics of the accidents, as well as the population of Barranquilla and the four indicators chosen to measure the severity of the data traffic accidents.

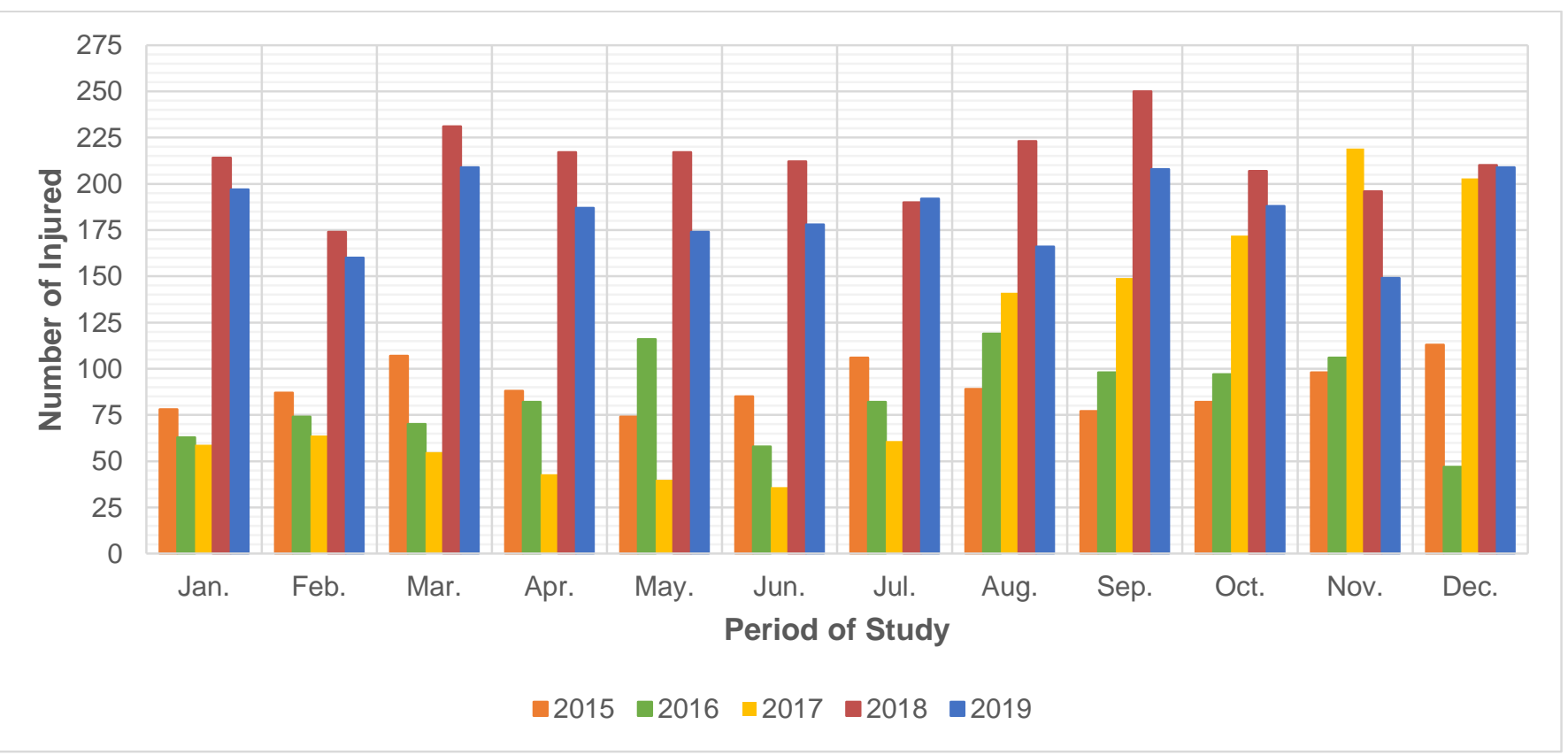

Fig. 3. Injured in road traffic accidents

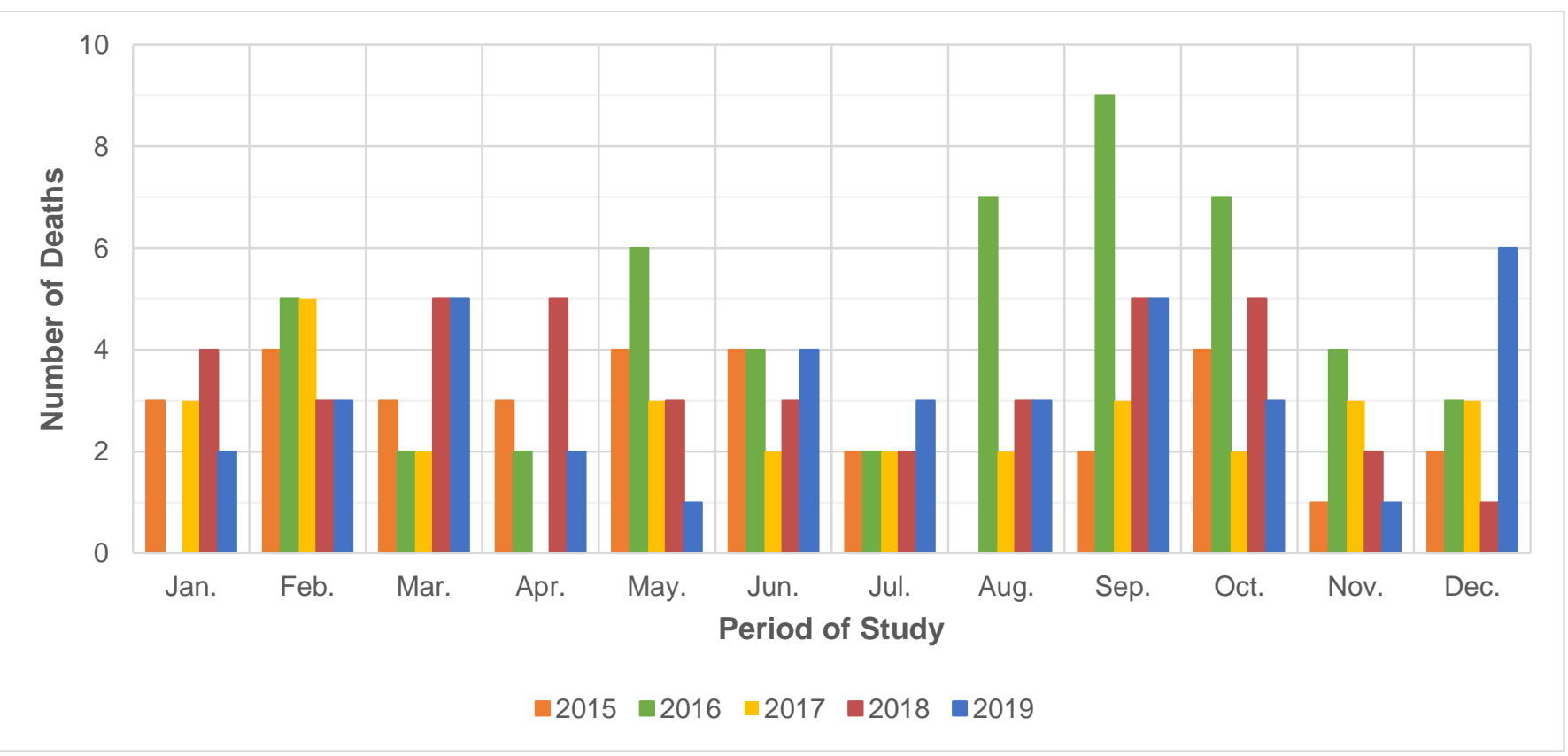

Fig. 4. Deaths in road traffic accidents 
International Journal of Engineering Research and Technology. ISSN 0974-3154, Volume 13, Number 10 (2020), pp. 2864-2869

(C) International Research Publication House. https://dx.doi.org/10.37624/IJERT/13.10.2020.2864-2869

Table 1. Types of victims or affected in traffic accidents

\begin{tabular}{cccccc}
\hline Year & With only Injured & With only Deaths & $\begin{array}{c}\text { With Injured and } \\
\text { Deaths }\end{array}$ & $\begin{array}{c}\text { With only } \\
\text { material damage }\end{array}$ & Total Accidents \\
\hline 2015 & 699 & 20 & 11 & 5,507 & 6,237 \\
2016 & 701 & 34 & 16 & 5,769 & 6,520 \\
2017 & 847 & 16 & 14 & 5,512 & 6,389 \\
2018 & 1,731 & 23 & 16 & 4,128 & 5,898 \\
2019 & 1,590 & 27 & 9 & 4,019 & 5,645 \\
\hline
\end{tabular}

Table 2. Typology of the traffic accidents

\begin{tabular}{ccccccc}
\hline Year & Crash & Run-over & Rollover & Occupant Fall & Fire & Others \\
\hline 2015 & 5,970 & 205 & 20 & 13 & 5 & 24 \\
2016 & 6,230 & 208 & 21 & 20 & 3 & 38 \\
2017 & 6,067 & 193 & 26 & 27 & 2 & 74 \\
2018 & 5,539 & 284 & 21 & 30 & 4 & 20 \\
2019 & 5,343 & 229 & 16 & 30 & 3 & 24 \\
\hline
\end{tabular}

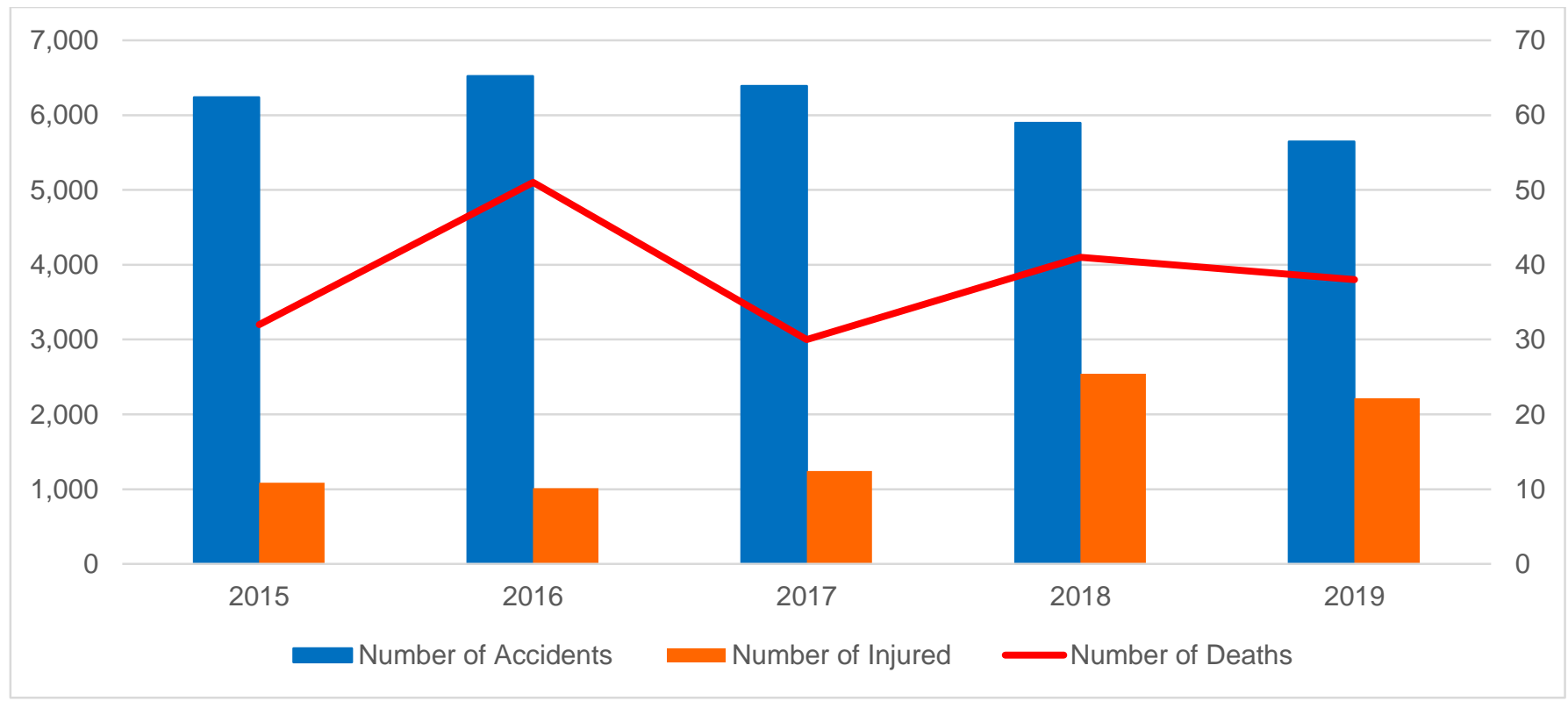

Fig. 5. Statistical data of accidents in Barranquilla

Table 3. Accident indicators in the city of Barranquilla

\begin{tabular}{ccccccccc}
\hline Year & $\begin{array}{c}\text { Number } \\
\text { of } \\
\text { Accidents }\end{array}$ & $\begin{array}{c}\text { Number } \\
\text { of } \\
\text { Injured }\end{array}$ & $\begin{array}{c}\text { Number } \\
\text { of } \\
\text { Deaths }\end{array}$ & Population & $\begin{array}{c}\text { Mortality rate } \\
\text { due to traffic } \\
\text { accident }\end{array}$ & $\begin{array}{c}\text { Injury rate } \\
\text { by traffic } \\
\text { accident }\end{array}$ & $\begin{array}{c}\text { Deaths/ } \\
\text { accident }\end{array}$ & $\begin{array}{c}\text { Fatality } \\
\text { rate (\%) }\end{array}$ \\
\hline 2015 & 6,237 & 1,084 & 32 & $1,138,048$ & 2.81 & 9.53 & 5.13 & 2.87 \\
2016 & 6,520 & 1,012 & 51 & $1,151,902$ & 4.43 & 8.79 & 7.82 & 4.80 \\
2017 & 6,389 & 1,242 & 30 & $1,168,679$ & 2.57 & 10.63 & 4.70 & 2.36 \\
2018 & 5,898 & 2,541 & 41 & $1,206,319$ & 3.40 & 21.06 & 6.95 & 1.59 \\
2019 & 5,645 & 2,217 & 38 & $1,243,056$ & 3.06 & 17.84 & 6.73 & 1.69 \\
\hline
\end{tabular}




\section{CONCLUSIONS}

According to the results obtained, it was possible to establish that the mortality and fatality rates presented the highest values for the year 2016. On the other hand, from the year 2017 onwards, a decrease in the number of registered accidents, as well as a significant decrease in the Fatality Rate, which is an indication that the accidents that occurred within the period 2017 - 2019 were less fatal.

\section{Acknowledgments}

The authors thank the engineer Edilberto Elias Contreras Sierra for the contributions made in the development of the manuscript.

\section{REFERENCES}

[1] Dorantes G, Cerda E, Tortosa F and Ferrero J. Accidentalidad de Automóviles de uso Particular en México: Influencia del Estrés y la Agresividad. Revista Latinoamericana de Ciencia Psicológica. 7(3):418-427. Doi: $10.5872 /$ psiencia/7.3.121

[2] INEGI. Síntesis Metodológica de la Estadística de Accidentes de Tránsito Terrestre en zonas Urbanas y Suburbanas (ATUS). 2009. Recovered from http://internet.contenidos.inegi.org.mx/contenidos/produc tos//prod_serv/contenidos/espanol/bvinegi/productos/met odologias/est/sm atus.pdf

[3] Cal y Mayor R, Cárdenas J. "Ingeniería de tránsito", 8th edition, Alfa Omega Grupo editor, México, 2007.

[4] Crespo C. Vias de comunicacion: Caminos, ferrocarroles, aeropuestos, puentes y puertos, Tercra edicion, Limusa, Mexico, 2004

[5] Mendoza A, Quintero F, Mayoral E. Secretaria de Comunicaciones y Transportes, Instituto Mexicano del Transporte. Seguridad Vial en Carreteras. Publicación Técnica No. 224, Sanfandila, Querétaro, México, 2003

[6] Garber N, Hoel L., "Ingeniería de tránsito y carreteras", tercera edición, Thomson editores, México, (2005)

[7] Departamento Administrativo Nacional de Estadística (DANE), Censo Nacional de Población y Vivienda. https://sitios.dane.gov.co/cnpv/app/views/informacion/per files/08001_infografia.pdf, 2020 (accessed 9 October 2020).

[8] Colombia Aprende - La red del conocimiento, Información General de Barranquilla. Error! Hyperlink reference not valid., 2016 (accessed 9 October 2020).

[9] Gómez AR, Orbe V, Campos Y. Morbilidad y mortalidad por accidentes de tránsito según componentes temporales, Ecuador. Revista KILLKANA Salud y Bienestar. 3 (1) (2019) 9-16. https://doi.org/10.26871/killcana_salud. v3i1.246.

[10] Farchi S, Molino N, Giorgi R, Piero B, Krzyzanowski M, Dalbokova D, Kim R. European Road Accident Indicator
Working Group, 2006. Defining a common set of indicators to monitor road accidents in the European Union. BMC Public Health 6, 183. https://doi.org/10.1186/1471-2458-6-183. 